DOI: 10.20472/AHC.2017.002.003

\author{
SUN JIAN \\ Beijing Institute of Technology, China
}

\title{
RESEARCH-LED DESIGN PRACTICE: A NEW APPROACH OF RESEARCH THROUGH DESIGN
}

\begin{abstract}
:
From the first action of human activity to invent tools, design has been regarded as craft and artefact creation. As a discipline, there is an ongoing debate between design research and practice. This research focuses on identification of design research from other traditional research fields, utilizing existing research methods to make design research more 'scientific 'but also reflect the essence of design as a discipline, there is needed a whole new view of research itself. Researcher-led design practice is regarded as a new approach to research through design to illustrate the relationship between design research and design practice. In research through practice approach, designers utilize their expertise in research tasks and conduct research to reflect on practice through building artefact as an important way to communicate knowledge and form theory.
\end{abstract}

\section{Keywords:}

design theory, design knowledge, artefact 


\section{Introduction}

For hundred years ago, human stated to making spears and tools, which might be the first action of design practice. Design as a discipline is quite young and the notion regarding the design as an innovation activity in twentieth century. Many design activates, particularly the physical ones have been embodied in handicraft(Friedman, 1997). "In one regard, design is a field of thinking and pure research"(Friedman, 2000). Research is about asking questions. Herbert Simon claims design as goals oriented activates. He writes, is to "[devise] courses of action aimed at changing existing situations into preferred ones"(Simon, 1982). Research through design is widely accepted as an important term to describe design research in a more practical way. This study trying to further this term to a term as 'research-led practice', which gives design research as the new definition.

\section{Research background}

According to Wikipedia, research is a systematic investigation into sources to demonstrate facts and reach new conclusions. The first definition of research dates from 1577, which firstly means diligent or careful search. Secondly, it means to investigate to discover facts, review existing theories through new findings, or apply such new theories. Lastly, it means information collection about a certain subject.

There used to a time that each academic field trying to transfer from a vague and ambiguous territory to a well-defined discipline. At that time, scholars and researchers, begin to take efforts to articulate research issues such as methods, methodology, philosophy, and related issues to shape this field(Friedman, 2003). Research is primarily associated with related knowledge in different areas. Richard Buchanan distinguishes research area from basic research, applied research and clinical research, while Archer (1979) identified academic research into three main fields that are humanities, science, and design.

Table 1: Comparison of research areas

\begin{tabular}{|l|l|l|}
\hline Author & Research field & Description \\
\hline $\begin{array}{l}\text { Archer } \\
\text { (1979) }\end{array}$ & Humanities & $\begin{array}{l}\text { Humanities focus on values of human and the } \\
\text { expression of the inner spirit of man. }\end{array}$ \\
\cline { 2 - 3 } & Science & $\begin{array}{l}\text { Science contributes to knowledge as to provide } \\
\text { understanding through observation, } \\
\text { measurement, and the generation of theory } \\
\text { and "the testing of theory by further observation } \\
\text { or experiment". }\end{array}$ \\
\cline { 2 - 3 } & Design & $\begin{array}{l}\text { Design contributes to knowledge as the study } \\
\text { of material culture and "the executive skills of } \\
\text { the doer and maker". }\end{array}$ \\
\hline
\end{tabular}




\begin{tabular}{|l|l|l|}
\hline $\begin{array}{l}\text { Buchanan } \\
(2001)\end{array}$ & Basic research & $\begin{array}{l}\text { A research for general abstracted principles, } \\
\text { which could be applied in a range of situations }\end{array}$ \\
\cline { 2 - 3 } & Applied research & $\begin{array}{l}\text { A research to adapt conclusions of basic } \\
\text { research to certain situation, in which to } \\
\text { develop and test the theory built in basic } \\
\text { research. Sometimes generate questions for } \\
\text { basic research. }\end{array}$ \\
\cline { 2 - 4 } & Clinical research & $\begin{array}{l}\text { A research to adapt findings of the other two } \\
\text { levels of research, in which to develop and test } \\
\text { the theory built in these two areas. Sometimes } \\
\text { clinical research generates questions for basic } \\
\text { and applied research. }\end{array}$ \\
\hline
\end{tabular}

In industry, most of the activities are restricted to clinical research because most companies are efficiency-oriented and they do not want to put much more time into other research fields. However, in academia, designers and researchers have the responsibilities to do design research in each level can ensure them to be fully conducted in which way new knowledge generated, such as theories, principles, models, methods and tools. Basic research in design could generate knowledge on the macro level, such as service design, sustainable design, interaction design, human-centred design, and inclusive design. These theories include models and principles in the certain area and focus a group of questions. Applied research in design lies on design methods, and tools. These design methods and tools generate from certain design theory but not restricted to it. These can be used to clinical research and text and develop design theories. Clinical research in design applies findings, develop, and test the theories. Clinical research sometimes generates new research questions and help with new theory building.

The Strategic Product Design program in TUDelft could best illustrate a good example of this research structure. This program focuses on the strategic value of design and contains theoretical disciplines and design practice. During research and practice, as any other disciplines, which include explicit knowledge and tacit knowledge, tacit knowledge was brought into articulate ways, which is the base of shared understanding(Friedman, 2000). With the theoretical background of strategic design, researchers study on design theories, which lead to plenty of design methods and tools as the guide to practical projects with cooperation companies. Through the application of methods and tools, problems are solved and new questions are generated, in which to develop the methods and sometimes build new theories.

In Simon's views, artificial design is should be along with objective sciences principles. This view was affected by computer science and engineering, which identify design as a rational, problem-solving activity. Archer also provides the perspective that design is a third kind of 'science' distinguished from humanities and traditional science. 'Design science' itself could 
draw on other fields of research methods to form its own discipline. Such when studying users perceive of certain products, some experiments methods from recognition psychology could be utilized, when studying the symbolic meaning of certain products, interview methods from anthropology are needed. Unlike strategies of most traditional research can be concluded into inductive reasoning and deductive reasoning, which determines "what is so" from observation and "what must be" from previous knowledge. The expertise of design is identified as a third kind of intelligence, or 'a third kind of logic ', which possible futures requires "abductive reasoning", or the ability of envisioning "what might be so"(Faste \& Faste, 2012).

\section{Defining design research}

How design research could identify from other traditional research fields, utilizing existing research methods to make design research more 'scientific 'but also reflect the essence of design as a discipline, there is needed a whole new view of research itself. Frayling (1993) first proposed theory of 'research into, by and for design'. Afterward, there are several other researchers give other opinions of design research. All of the theories have inner correlations and distinctions. This is the analysis the views of design research from them.

Table 2: Comparison of design research categories

\begin{tabular}{|l|l|l|}
\hline Author & Category & Description \\
\hline $\begin{array}{l}\text { Frayling } \\
\text { (1993) }\end{array}$ & $\begin{array}{l}\text { Research into } \\
\text { design }\end{array}$ & $\begin{array}{l}\text { Research into design refers to "historical research, } \\
\text { aesthetic or perceptual research and theoretical } \\
\text { perspectives on art and design", which often leads to a } \\
\text { Ph.D. thesis. }\end{array}$ \\
\cline { 2 - 4 } & $\begin{array}{l}\text { Research } \\
\text { through design }\end{array}$ & $\begin{array}{l}\text { Research through design refers to "material research, } \\
\text { development work and action research", which often studio } \\
\text { projects, which is often involved with studio projects and } \\
\text { "for the Ph.D. studio work plus a more extensive and } \\
\text { substantial research report". }\end{array}$ \\
\cline { 2 - 4 } & $\begin{array}{l}\text { Research for } \\
\text { design }\end{array}$ & $\begin{array}{l}\text { Research for design is the "research where the end product } \\
\text { is an artefact ", where "the goal is not primarily } \\
\text { communicable knowledge in the sense of verbal } \\
\text { communication, but in the sense of visual or iconic of } \\
\text { imagistic communication". }\end{array}$ \\
\hline $\begin{array}{l}\text { Friedman } \\
(2008) \\
\text { Research into }\end{array}$ & $\begin{array}{l}\text { Research into design is to reagrd design as a discipline, to } \\
\text { develop a general theory to "support application theories } \\
\text { and operational programs". }\end{array}$ \\
\hline
\end{tabular}




\begin{tabular}{|c|c|c|}
\hline & $\begin{array}{l}\text { Research by } \\
\text { design }\end{array}$ & $\begin{array}{l}\text { Research by design is not "tacit knowledge and design } \\
\text { practice as a new form of theorizing", and require more } \\
\text { thought. }\end{array}$ \\
\hline & $\begin{array}{l}\text { Research for } \\
\text { design }\end{array}$ & $\begin{array}{l}\text { Research for design is to "consider the explicit ways in } \\
\text { which we can build design theory" and to create "theory- } \\
\text { based knowledge". }\end{array}$ \\
\hline \multirow[t]{4}{*}{$\begin{array}{l}\text { Faste and } \\
\text { Faste } \\
(2012)\end{array}$} & $\begin{array}{l}\text { Design through } \\
\text { research }\end{array}$ & $\begin{array}{l}\text { Design through research refers as studious design } \\
\text { research, which is "synonymous with the } \\
\text { research practices of other conventional fields of research". }\end{array}$ \\
\hline & $\begin{array}{l}\text { Design } \\
\text { research }\end{array}$ & $\begin{array}{l}\text { Design of research refers as formative design research, } \\
\text { which is "the process by which research activities are } \\
\text { routinely designed". }\end{array}$ \\
\hline & $\begin{array}{l}\text { Research on } \\
\text { design }\end{array}$ & $\begin{array}{l}\text { Research on design refers as diagnostic design research, } \\
\text { which is "the critical role of examining design } \\
\text { processes to enhance the effectiveness and efficiency of a } \\
\text { given design method or process". }\end{array}$ \\
\hline & $\begin{array}{l}\text { Research } \\
\text { through design }\end{array}$ & $\begin{array}{l}\text { Research through design refers as embedded design } \\
\text { research, which is "the knowledge generated is contained } \\
\text { in the cognitive processes and artefacts of the design } \\
\text { activity performed", and "is closely related to research } \\
\text { through practice in disciplines such as studio art where } \\
\text { similar processes result in the creation of experienced } \\
\text { artefacts" (Koskinen et al. 2011). }\end{array}$ \\
\hline
\end{tabular}

Therefore, research is about asking questions on different levels, such as basic, applied, and clinical. Research in different forms asks different questions. Similarly, design research is also about asking questions. On the different level of design, research asks questions from the different perspective and sometimes generate questions to another level. To conclude research above, this research divide design research into three categories.

The first category is research into/of design, which is also the most basic forms of design research. On the basic level of design research, scholars often try to create a model by describing how elements in relation to one another. In terms of the design area, researchers often demonstrate a serious of historical movements. Critical thinking and systemic inquiry are necessary when forming the foundation of theory. Elements from another area of social science, such as politics, economy and culture influence design for its forming as we see in nowadays. In the basic form of design research, there is often comes with theories or models. "It is theory 
and the models that theory provides through which we link what we know about what we do"(Friedman, 2003). Some theories show the origin of such insights and the social or/and scientific reasons behind them. Some models describe how elements function in a dynamic way and the interaction between the process and action.

The second category is research through/by design, which can be referred as embedded design research. In some research, research through practice is viewed as action research(Archer, 1995). Archer (1995) also defined action research as a "systematic investigation through practical action calculated to device or test new information, ideas, forms or procedures and to produce communicable knowledge". This kind of research activity could generate the knowledge both in theory and artefacts when performing design, and "is closely related to research through practice in disciplines such as studio art where similar processes result in the creation of experienced artefacts"(Koskinen, Zimmerman, Binder, Redstrom, \& Wensveen, 2011).

The third category is research on/for design, on which level researchers and designers shape research at the clinical level of practice. In this kind of research activities, researchers put efforts in observing designers and design practice directly to improve the efficiency of design skills and communication skills, which are often by doing research on designers in practice or doing experiments to test influences that affect design behaviours(Faste \& Faste, 2012). By illustrating design process, research on design and research for design validate the design practice in different ways, such as collaboration mechanisms of in team design activities(Brereton, Cannon, Mabogunje, \& Leifer, 1996) or prototyping behaviour(Dow \& Klemmer, 2011).

In conclusion, the first category describes the design as a discipline, the second category forms design as a discipline and the last category conduct study into the design as a discipline.

\section{Research through design and Research led design practice}

From the discussion above, research through design is the main approach to form design research as a discipline. Kotlarewski, Kuys, and Thong (2016) claim that research through design as the "act of practicing research, design, and reflection". "Research is a practice, writing is a practice, doing science is a practice, doing design is a practice, making art is a practice"(Frayling, 1993). Research through design emphasized the close relationship between design research and design practice. In this view, the results and findings are utilized and directly affect design practice, though diverse methods of design practice methods, such as sketches, prototyping, and modeling to form knowledge. In practice, the outcome of research and value, and sometimes new questions emerge which leads to a new research topic. At the same time, practice is the reflection of research, embody research outcome of practicing articulate designers' insights of the particular situation, and transform tacit knowledge into explicit knowledge. Sometimes, the design of new products could be seen as a way of communicating research findings.

"Research through the design of products has been hindered by the lack of any fundamental documentation of the design process which produced them.

Too often, at best, the only evidence is the object itself, and even that 
evidence is surprisingly ephemeral. Where a good sample of the original product can still be found, it often proves to be enigmatic."(Frayling, 1993)

This quote indicates the lack of documentation of the process in products design. Sometimes, products are shown as the evidence but often are regarded as temporary. However, if the whole process of products developing documentary and reflection of research outcome could be revealed, the efforts would lead to generating knowledge, helping transform tacit knowledge into explicit knowledge, and what is most important, strengthening the core function of the artefact of being knowledge itself. From this point of view, there is a great demand of research in practice, especially from the academic side of doing design research.

Since the phrase "research through design" firstly came up in 1990s, scholars afterward had been done research to find the theory(Findeli, 1998). Since then, a variety of examples has put "research through design" into practice. Some of them can be seen from the design Ph.D. programs at Royal College of Art and the Illinois Institute of Technology. Some can be seen in the trend of peer-reviewed exhibitions in events like the Design Research Society conferences(Grocott, 2010) and some others can be seen from the design practice projects from the academia.

At the same time, there are debates about what is research through design after the phrase was brought up but at the same time, help to build the process of doing design research. Most of the debates are around seeing design as 'science' or 'the reflection of practice'. To understand the theoretical framework of understanding design as either 'science' or 'the reflection of practice', it is necessary to track back the paradigm in the field of philosophy. According to Mackenzie and Knipe (2006), paradigm influences the approach knowledge is studied, and "it is the choice of the paradigm that sets down the intent, motivation, and expectations for the research." The phrase 'paradigm' is defined as "a loose collection of logically related assumptions, concepts, or propositions that orient thinking and research"(Bogdan \& Biklen, 1998). In positivism studies, the main role of the researcher is collecting and interpreting data through an objective approach and the research findings are usually objective and observable, and they often view the research could generate facts and the regard the world to be objective.

The framework of 'design science' can be described as the theoretical paradigms of positivism, which comes from the origin of design methodology, which is firstly influenced by the theories of technical systems(Dorst \& Dijkhuis, 1995). From this view, design research through practice is regarded as a rational activity, and design problems can be solved in logic ways, which reflects design study framework of Simon. In his work, Science of the Artificial, Simon provides the scope of design studies from the framework of sound and rigorous of design methods. $\mathrm{He}$ tries to utilize research methods from traditional science fields and views the design research process through objective observation, rational analysis, and direct generation. From this perspective, design is regarded as a logical and rational process which as been the primary basis of shaping design methodology in nowadays design education(Dorst \& Dijkhuis, 1995). It can also be seen that this kind of research through design rely heavily on research methods and the access to data. The more process-oriented approach is more likely to search and a more linear way to find 'truth'. Simon's positivist view on design is still the predominant one in 
design research and education. As we can see, many design educators today apply a series of design methods and tools to do design research. After a sequence of 'objective' analysis and observation, there comes the outcome, in which, why the design process is viewed as a scientific process. The view of design as rational problem-solving process gives a more stable basis to design research and has constituted the majority design knowledge nowadays.

Another paradigm is constructivist. Constructivism in psychology argues that each person perceives the world differently and their own meaning of certain situation and action. Therefore, the actual world has a different meaning for each single individual. That is the same as in design activities. Each design project is unique and has its own situation. Designers involved in the same project have their own personal perceptions of such situation. In addition, there are many ways to describe design processes, and each designer or researcher would have their own way to carry out design activities.

Following Simon, Schön's introduced another approach to cognitive design theory, which is known as "reflective activity". Other terms are used: relation notions, "reflective practice", or "explicit reflection that happens in the context of the design task at hand". The reflective practice aims to reveal the interaction between design process, design objective, and designers. The main idea of reflective practice is seeing design activity as a dynamic process. Designers subjectively understand the design task and context, lead design steps and the process by personal insights and reflect that into design actions. The core description of the theory by Schön can be illustrated by the quote:

"Through the unintended effects of the action, the situation talks back. The practitioner, reflecting on this back talk, may find new meanings in the situation which leads him to a new reframing. " (Schon, 1983)

According to him, reflection-in-action refers to the "action present", which encompasses the "time in which action can still make a difference to the situation". "The action present may stretch over minutes, hours, days, or even weeks and months, depending on the pace of the activity and the situational boundaries that are characteristic of the practice" (Schon, 1983).

After Schön, Cross (2006)claims the importance of practitioner reflection throughout the process of design practice, because "practitioner reflection plays an important role in communicating knowledge through product creation to a wide audience and demonstrate the results of the methodical and disciplined process". Within which, the importance of designers' expertise, especially the tacit part plays an important role in design tasks. Friedman (2008) also states that "tacit knowledge is reflected in the larger body of distributed knowledge embedded in social memory and collective work practice", and "our stock of tacit knowledge enables us to practice". "Reflective practice itself rests on explicit knowledge rather than on tacit knowledge" (Friedman, 2008).

Schön identifies the fact that each design task is unique and there is not a universal method to solve design problems, so designers should have the expertise to determine how to solve the problem in a particular situation. "In contrast to analysts or critics, designers put things together and bring new things into being, dealing in the process with many variable and constraints, some initially known and some discovered through designing. Designers judge variable, 
reconcile conflicting values, and maneuver around constraints- a process in which, although some design products may be superior to others, there are no unique right answers." (Schön, 1987)

However, the theory might put too much emphasis on designers' personal perspectives on design activity. In real design projects, when designers are playing more important roles in the industry, they are not just making decisions upon the material and physical conditions but also a broader range of social and cultural perspevtives. So, research is needed to help with the intuition. When conducting design practice within a research project and the act of practice is reflected upon the research process and at the same time converted to an explicit knowledge to help with the process of the whole design program, then design practice becomes a key contributor to design research. So, it came to the similar conclusion that design practitioners cannot claim practice itself is research, but the importance of reflective practice is to enable designers to use their tacit knowledge for research but it must be reflected upon and converted into explicit knowledge.

Under the background of constructivist paradigm, another research through design approach is brought up by Koskinen et al. (2011) as "constructive design research", which means "'research through construction, such as products, systems or spaces becomes the central ways in generating knowledge"(Koskinen et al., 2011)." From this perspective, a more important and meaningful approach to combine design with research is brought up. Even so, the theory comes from the constructivist in philosophy that knowledge is constructed by the general understanding of the situation rather than strictly rational induction, in the design field, it refers to more tangible things. They focus the importance of tangible outcomes building in research projects. As the quote of Joseph (2004) "[first] design-based research creates opportunities for focusing on key questions... [Second] design-based research supports design process with both formal research backing and rapid prototyping... And, [third] in design-based research, emergent theory shapes research methods as well as design".

Following Koskinen, Kuys, Thong, Kotlarewski, and Thompson-Whiteside (2014) illustrate "constructive design research" as "research-led industrial design". They put the relation between design research and design practice to a further degree, which amplifies the importance of practice to form the knowledge of design research, but also, what is more important, to demonstrate the leading role of design research. Because "the advantage of the scholarly approach of research-led industrial design is the reduction in risk associated with the product developed. That is, by understanding the material to be used and the application possibilities the designer is able to reduce the cost of prototyping and testing designs. "(Kotlarewski et al., 2016)

Just as Dorst (2008) claims that design researcher should have the capability of understanding of the object and context in a deeper and systematic way to enrich academic design research works. "This statement is used to legitimize the intentions of this study by promoting the designer, the design context and most importantly the physical manifestations of research-led practice in scholarly design research, with a direct focus on a new contribution to knowledge that is accessible to industry "(Kuys et al., 2014) 


\section{Conclusion}

All of these theories identified the importance of artefact in research-led industrial design practice. Biggs (2002) referred to artefacts as an important way to embody knowledge and "neither artefacts alone nor words/texts alone would be sufficient" in design research". To claim that the artefact is a substitute for written words, it must be claimed that the development of an artefact is a form of explicit knowledge that is presented to a wider audience outside of the field of design and research." (Kotlarewski et al., 2016)

"Researchers make prototypes, products, and models to codify their own understanding of a particular situation and to provide a concrete framing of the problem and a description of a proposed, preferred state... Designers focus on the creation of artefacts through a process of disciplined imagination, because artefacts they make both reveal and become embodiments of possible futures... Design researchers can explore new materials and actively participate in intentionally constructing the future, in the form of disciplined imagination, instead of limiting their research to an analysis of the present and the past."(Zimmerman \& Forlizzi, 2008)

However, that is not to say that design researchers' contribution is restricted to the artefact rather than theory producing. As design, researchers have a deeper understanding design tasks, process, and objects. Theories are often built during and process and "the design researcher creates artefacts that embody hypotheses and places them in the real-world for testing"(Joseph, 2004). Therefore, design researchers create artefacts not only as a way of communicating knowledge, but also to form and as text theory. Sometimes, new questions emerge and lead to new research topics.

In conclusion, the term "research-led design practice" reveals design researchers' role in research through practice approach, which means designers utilize their expertise in research tasks and conduct research to reflect on practice through building artefact as an important way to communicate knowledge and form theory.

\section{References}

Archer, B. (1979). Design as a discipline. Design Studies, 1(1), 17-20.

Archer, B. (1995). The nature of research. Co-Design Journal, 2(11), 6-13.

Biggs, M. (2002). The role of the artefact in art and design research. International journal of design sciences and technology, 10(2), 19-24.

Bogdan, R. C., \& Biklen, S. K. (1998). Foundations of qualitative research in education. Qualitative research in education: An introduction to theory and methods, 1-48.

Brereton, M. F., Cannon, D. M., Mabogunje, A., \& Leifer, L. J. (1996). Collaboration in design teams: How social interaction shapes the product. Analysing design activity, 319-341. 
Buchanan, R. (2001). Design research and the new learning. Design issues, 17(4), 3-23.

Crowther, D., \& Lancaster, G. (2008). Research Methods: a Consice Introduction to Research in Management and Business Consultancy: Oxford: Butterworth-Heinemann.

Dorst, K. (2008). Design research: a revolution-waiting-to-happen. Design Studies, 29(1), 4-11.

Dorst, K., \& Dijkhuis, J. (1995). Comparing paradigms for describing design activity. Design Studies, 16(2), 261-274.

Dow, S. P., \& Klemmer, S. R. (2011). The efficacy of prototyping under time constraints Design Thinking (pp. 111-128): Springer.

Faste, T., \& Faste, H. (2012). Demystifying "design research": Design is not research, research is design. Paper presented at the IDSA Education Symposium.

Findeli, A. (1998). A quest for credibility: Doctoral education and research in design at the University of Montreal. Doctoral Education in Design, 99-116.

Frayling, C. (1993). Research in art and design.

Friedman, K. (1997). Design science and design education: Norwegian School of Management.

Friedman, K. (2000). Creating design knowledge: from research into practice.

Friedman, K. (2003). Theory construction in design research: criteria: approaches, and methods. Design Studies, 24(6), 507-522.

Friedman, K. (2008). Research into, by and for design. Journal of Visual Art Practice, 7(2), 153-160.

Grocott, L. (2010). Design Research \& Reflective Practice: The facility of design-oriented research to translate practitioner insights into new understandings of design.

Joseph, D. (2004). The practice of design-based research: Uncovering the interplay between design, research, and the real-world context. Educational Psychologist, 39(4), 235-242.

Koskinen, I., Zimmerman, J., Binder, T., Redstrom, J., \& Wensveen, S. (2011). Design research through practice: From the lab, field, and showroom: Elsevier.

Kotlarewski, N. J., Kuys, B., \& Thong, C. (2016). Design innovation: a tool for value-adding to the Papua New Guinea balsa wood industry. Journal of Design, Business \& Society, 2(2), 183-196.

Kuys, B., Thong, C., Kotlarewski, N., \& Thompson-Whiteside, S. (2014). Research-led practice in design research used to best demonstrate design theories. Design Research Society (DRS), Umea University, Umea, Sweden, 16-19.

Schon, D. (1983). The reflective practitioner: New York: Basic Books.

Schön, D. A. (1987). Educating the reflective practitioner: Toward a new design for teaching and learning in the professions: Jossey-Bass.

Simon, H. A. (1982). Models of bounded rationality: Empirically grounded economic reason (Vol. 3): MIT press. 
Zimmerman, J., \& Forlizzi, J. (2008). The role of design artifacts in design theory construction. Artifact, 2(1), 41-45. 